\title{
THE INFLUENCE OF THE Y-CHROMOSOME ON QUANTI- TATIVE CHARACTERS OF D. MELANOGASTER
}

\author{
CLAUDIO BARIGOZZ! \\ Istituto di Genetica, Università di Milano
}

\section{INTRODUCTION}

Received I5.ii.5 I

LitTLE is known about the genetical action exerted by the heterochromatin in general, and by the Y-chromosome in particular. The information available is so scanty, that many scientists consider heterochromatin as inert, i.e. devoid of genetical activity.* Nonetheless some investigations indicate that a peculiar kind of control on certain characters is exerted also by the Y-chromosome on abdominal chæta of Drosophila melanogaster (Mather, 1944), less clearly on variegation (Demerec, I940, I94I ; Schultz, I94 I, I 947), and finally on the wing hairs, and other small characters (Barigozzi, I948, I949). In other species, a genetical activity was proved for the heterochromatin of Spharocarpus (Knapp, 1935), of Sorghum (Darlington and Thomas, I94 I) and of Anthoxanthum (Oestergren, 1947). Also in some Rynchota, Darlington (1939) put forward a possible action of small heterochromatic elements. Following a completely different line, Caspersson and Schultz (1938) and Caspersson (1940) gave some evidence for the presence of a centre for protein and polynucleotide synthesis in the heterochromatin. According to this view, we have a second reason to believe that heterochromatin is not inert.

No more than an introduction to the knowledge of the heterochromatin role has thus been worked out as yet. Even though heterochromatin is likely to produce only small effects, we do not know the kind of characters affected by it.

The present paper, $\uparrow$ which includes some data previously published (Barigozzi, I948, I949; Di Pasquale, I95I) should be a contribution to the knowledge of such characters which, differing between male and female, can be supposed to be controlled by the Y-chromosome, known as completely heterochromatic.

\section{MATERIAL, METHODS AND TECHNIQUE}

The characters chosen for the present investigation have been the following: (I) frequency of unicellular hairs of a given portion of the wing, (2) size of the cornex of the compound eyes, (3) irregularities

* The few major genes localised in the $\mathrm{Y}$, as bobbed, are not considered here.

$\dagger$ For the statistical elaboration, I am indebted to the courtesy of Professor K. Mather, who gave me valuable advice. 
of distribution in the corneal complex of the compound eyes. All these characters are alike in being formed from a fixed number of cells. In fact, each wing hair corresponds to one single cell (Dobzhansky, 1929). The corneæ are likely built from two cells, and the irregularities of distribution are due to the presence of single cornex of unusual size (Di Pasquale, I95I). This means that a common factor plays a role in all these characters, i.e. the cell size. The action exerted by the Y-chromosome was detected by means of stocks, constructed in order to have each a peculiar $\mathrm{Y}$ and a set of the remainder chromosomes identical in all stocks. The Y's were obtained from the wild stocks: Oregon R, Oerlikon, Crkwenika, and Luino. The other chromosomes came for all the stocks from Oregon R. Various Y-chromosomes were placed on a background of Oregon chromosomes ("oregonised") by the following two procedures.

I. Repeated backcrosses of heterozygous males to Oregon females. According to Mather (1944), the oregonisation can be considered practically complete after 7 generations of backcrosses, if single males are used.

2. Substitution of full chromosomes by means of crosses between the Oregon stock, which shall provide all the chromosomes except the $\mathrm{Y}$, and a stock with the $\mathrm{X}$ and autosomes marked with dominants and provided with structural changes preventing crossing-over. In the present investigation the procedure was developed in the following manner :-

(a) Construction of stocks with the desired $\mathrm{Y}$ and marked chromosomes.

$$
\begin{aligned}
& \frac{\mathrm{Y}^{\text {Luino }}}{+} \quad \frac{\mathrm{P} m}{\mathrm{C} y \mathrm{~L}} \quad \frac{\mathrm{S} b \mathrm{Me}}{\mathrm{H}} ; \frac{\mathrm{C}_{\mathrm{I}} \mathrm{B}}{+} \quad \frac{\mathrm{P} m}{\mathrm{C} y \mathrm{~L}} \frac{\mathrm{S} b \mathrm{M} \dot{e}}{\mathrm{H}} \times \\
& \frac{\mathrm{Y}^{\text {Crkweniza }}}{+} \frac{\mathrm{P} m}{\mathrm{C} y \mathrm{~L}} \frac{\mathrm{S} b \mathrm{M} e ́}{\mathrm{H}} ; \quad \text { or }
\end{aligned}
$$

(b) $\frac{\mathrm{Y}^{\text {Luino }}}{+} \quad \frac{\mathrm{P} m}{\overline{C y} \mathrm{~L}} \frac{\mathrm{S} b \mathrm{M} \dot{e}}{\mathrm{H}} \times \frac{x^{O r}}{x^{O r}} \frac{\mathrm{II}^{O r}}{\overline{\mathrm{II}}^{O_{r}}} \frac{\mathrm{III}^{O^{O r}}}{\overline{\mathrm{I}} \mathrm{I}^{O^{r}}}$

$$
\frac{\mathrm{Y}^{\text {Luino }}}{x^{O r}} \frac{\mathrm{P} m}{\mathrm{II}^{o r}} \frac{\mathrm{S} b \mathrm{M}_{e}}{\mathrm{III}^{O r}} \times \frac{\mathrm{CI}_{\mathrm{I}} \mathrm{B}}{x^{O r}} \frac{\mathrm{C} y \mathrm{~L}}{\mathrm{II}^{O r}} \quad \frac{\mathrm{H}}{\overline{\mathrm{III}}^{o r}}
$$

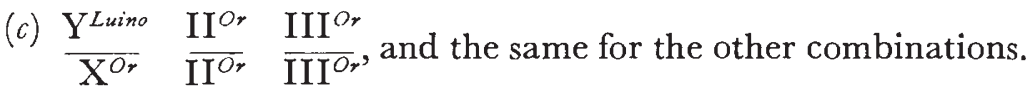

This technique is based on the assumption that the Oregon- $\mathrm{R}$ stock is practically isogenic. A disadvantage lies in disregarding the IVth pair. But a comparison between the results obtained with method (I) and (2) permits the conclusion that no appreciable difference exists between the methods.

In this manner the way is open to compare individuals with $\mathrm{Y}$ 
(males) and individuals without (females). The remainder of the genome being identical, every discrepancy in sex difference must be ascribed to differences of the genes contained in the Y-chromosome, to the difference in gene dosage, when a single $\mathrm{X}$ or two $\mathrm{X}$ 's are present, or to a maternal effect.

The counting of the hairs was made on wings detached from the individual and mounted in glycerine. The surface within which the counting was made, was determined by a reticulum introduced into the eye-piece of the microscope. In all observations, the magnification has been of circa 960 . The hairs were counted considering the emerging points of those hairs comprised in two adjacent squares, adjusting the preparation to show the region located immediately below the first crossvein, on the superior surface.

The cornex were observed detached from the eye after treatment with aqueous $\mathrm{KOH}$ solution, and mounted in glycerine.

The measurements of the cornex (expressed in $\mu^{2}$ ) were made with the help of the camera lucida, with a magnification of circa $95^{\circ}$ diameters. For each individual, ıo corneæ were measured and then the mean was calculated. The irregularities-whose frequency was also counted-resulted from differences in size of corneæ, producing disorders of the corneæ distribution, in individuals of the genotype

$$
\frac{\mathrm{S} b c r / n\left({ }_{3} \mathrm{R}\right) \mathrm{M} \dot{e}}{\mathrm{III}^{d} \mathrm{C} h r} \text { (Di Pasquale, I 95I). }
$$

The statistical treatment was made using the following methods :-

I. The comparison between the means of the hair frequencies was made with the $\sigma_{d}$ or error of the difference, where the number of individuals was not less than $5^{\circ}$.

In one case (Luino), for which only smaller samples were used, the comparison was made by the analysis of the variance.

2. When the individuals did not reach 50 , the means were compared with the $t$ test.

3. The frequency of the irregularities of corneæ location follows a Poissonian-like distribution. The comparison between sexes was made with the $\chi^{2}$, grouping the classes in order to eliminate those with a frequency less than 5 .

\section{OBSERVATIONS}

A.-Four wild stocks were investigated for the characters : hair frequency, corneal size, frequency of irregularity of the cornex. Here are the data and the statistical treatment as indicated, for testing the significance of the difference between sexes. 


\section{OREGON}

I. Hairs.-This stock has been investigated twice and the following figures have been obtained.

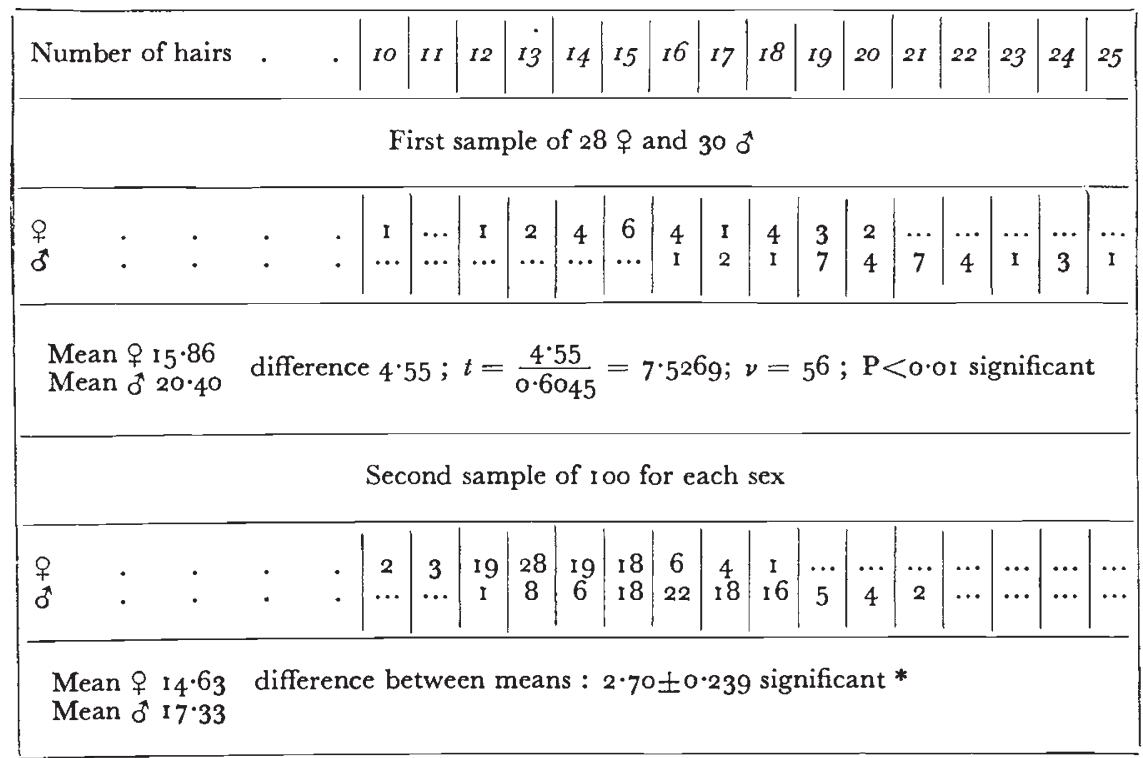

* The strong difference between the means is explained by the time which occurred between the countings. The same phenomena will be observed for the corneal irregularities see later).

2. Cornea.-Thirty individuals for each sex (see table 1) :-

TABLE I

Surfaces in $\mu^{2}$ of the cornee of Oregon

\begin{tabular}{|c|c|c|c|c|c|c|c|c|c|}
\hline \multicolumn{5}{|c|}{ 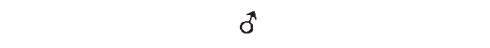 } & \multicolumn{5}{|c|}{ 우 } \\
\hline $\begin{array}{l}538 \\
587 \\
646 \\
647 \\
657 \\
663\end{array}$ & $\begin{array}{l}664 \\
668 \\
677 \\
679 \\
681 \\
689\end{array}$ & $\begin{array}{l}708 \\
710 \\
729 \\
729 \\
760 \\
761\end{array}$ & $\begin{array}{l}769 \\
776 \\
795 \\
795 \\
801 \\
811\end{array}$ & $\begin{array}{l}815 \\
816 \\
834 \\
845 \\
846 \\
864\end{array}$ & $\begin{array}{l}643 \\
654 \\
692 \\
693 \\
728 \\
741\end{array}$ & $\begin{array}{l}753 \\
762 \\
767 \\
772 \\
778 \\
785\end{array}$ & $\begin{array}{l}800 \\
814 \\
822 \\
826 \\
872 \\
891\end{array}$ & $\begin{array}{l}892 \\
902 \\
9^{10} \\
9^{1} 3 \\
9^{2} 8 \\
939\end{array}$ & $\begin{array}{r}939 \\
955 \\
963 \\
983 \\
983 \\
1127\end{array}$ \\
\hline $\begin{array}{l}\text { Total } \\
\text { Means }\end{array}$ & \multicolumn{4}{|c|}{$\begin{array}{c}3^{\circ} \\
73^{2} \cdot 0\end{array}$} & \multicolumn{5}{|c|}{$\begin{array}{c}30 \\
840 \cdot 9\end{array}$} \\
\hline
\end{tabular}

Difference $180.9 ; t=\frac{108.9}{25.53}=4.265 ; \nu=58 ; \mathrm{P}>0.01$. The difference is significant. 


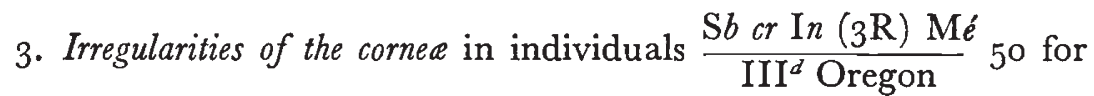
each sex :-

\begin{tabular}{|c|c|c|c|c|}
\hline $\begin{array}{c}\text { Number of } \\
\text { irregularities }\end{array}$ & $q$ & 0 & Total & $\chi^{2}$ \\
\hline 0 & 47 & 29 & 76 & $\begin{array}{c}4 \cdot 263 \\
13 \cdot 500\end{array}$ \\
\hline$>0$ & 3 & 21 & 24 & $17 \cdot 763$ \\
\hline Mean & 0.06 & 0.66 & $\cdots$ & 17 \\
\hline
\end{tabular}

Difference 0.60 significant $; \chi^{2}=17 \cdot 763 ; \nu=1 ; P>0 \cdot 01$

One remarks that in all the investigated characters, the difference between the sexes is significant.

\section{OERLIKON}

I. Hairs.-One hundred for each sex.

First sample 1948

\begin{tabular}{|c|c|c|c|c|c|c|c|c|c|c|c|c|c|c|c|c|}
\hline \multicolumn{4}{|c|}{ Number of hairs. } & & 12 & 13 & 14 & 15 & I6 & 17 & 18 & 19 & 20 & $2 I$ & 22 & Means \\
\hline \multirow[t]{2}{*}{$\begin{array}{l}\text { q } \\
\text { o }\end{array}$} & \multirow[t]{2}{*}{. } & \multirow[t]{2}{*}{. } & \multirow{2}{*}{ • } & \multirow{2}{*}{\multicolumn{2}{|c|}{$\begin{array}{c}2 \\
\cdots\end{array}$}} & \multirow[t]{2}{*}{$\begin{array}{l}10 \\
\cdots\end{array}$} & \multirow[t]{2}{*}{$\begin{array}{r}16 \\
I\end{array}$} & \multirow[t]{2}{*}{$\begin{array}{r}29 \\
2\end{array}$} & \multirow[t]{2}{*}{$\begin{array}{r}2 \mathrm{I} \\
4\end{array}$} & \multirow[t]{2}{*}{$\begin{array}{l}\text { I7 } \\
15\end{array}$} & \multirow[t]{2}{*}{$\begin{array}{r}2 \\
24\end{array}$} & \multirow[t]{2}{*}{$\begin{array}{r}3 \\
27\end{array}$} & \multirow[t]{2}{*}{ I7 } & \multirow[t]{2}{*}{$\ddot{7}$} & \multirow[t]{2}{*}{ 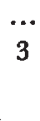 } & $\begin{array}{l}15.31 \\
18.61\end{array}$ \\
\hline & & & & & & & & & & & & & & & & Difference $3 \cdot 30 \pm 0 \cdot 209$ \\
\hline
\end{tabular}

The differences between sexes is significant

Second sample 1949

\begin{tabular}{|c|c|c|c|c|c|c|c|c|c|c|c|c|c|c|c|c|}
\hline \multicolumn{4}{|c|}{ Number of hairs. } & & & 13 & 14 & 15 & 16 & 17 & 18 & 19 & 20 & $2 I$ & 22 & Means \\
\hline \multirow[t]{2}{*}{$\begin{array}{l}q \\
q \\
b\end{array}$} & \multirow[t]{2}{*}{. } & & \multirow[t]{2}{*}{ • } & \multirow{2}{*}{\multicolumn{2}{|c|}{$\ddot{\text { I }}$}} & \multirow[t]{2}{*}{$\begin{array}{c}3 \\
. \cdot\end{array}$} & \multirow[t]{2}{*}{$\mid \begin{array}{l}7 \\
3\end{array}$} & \multirow[t]{2}{*}{$\begin{array}{r}18 \\
4\end{array}$} & \multirow[t]{2}{*}{$\begin{array}{l}27 \\
16\end{array}$} & \multirow[t]{2}{*}{$\begin{array}{l}29 \\
29\end{array}$} & \multirow[t]{2}{*}{$\begin{array}{l}\text { I I } \\
17\end{array}$} & \multirow[t]{2}{*}{$\begin{array}{r}4 \\
17\end{array}$} & \multirow[t]{2}{*}{$\ddot{7}$} & \multirow[t]{2}{*}{$\begin{array}{l}\text { I } \\
3\end{array}$} & \multirow[t]{2}{*}{$\ddot{3}$} & $\begin{array}{l}16 \cdot 27 \\
17 \cdot 71\end{array}$ \\
\hline & & & & & & & & & & & & & & & & Difference $1 \cdot 44 \pm 0.227$ \\
\hline
\end{tabular}

The difference is significant.

If we compare the means of the samples, testing for the hair frequencies the standard error of the difference, we obtain :-

Difference between females : $0 \cdot 96 \pm 0 \cdot 204$

Difference between males : $0.90 \pm 0.231$

We can conclude that the difference is significant, since the error does not reach the third of the difference.

2. Cornee not measured. 
3. Irregularities of the cornee in individuals $\frac{\mathrm{S} b c r \mathrm{In}(3 \mathrm{R}) \mathrm{M} \dot{e}}{\mathrm{III}^{d} \text { Oerlikon }}$ :-

(a) First sample, 1948, of 61 individuals for each sex

\begin{tabular}{|c|c|c|c|c|}
\hline $\begin{array}{l}\text { Number of } \\
\text { irregularities }\end{array}$ & q & $\sigma^{*}$ & Total & $\chi^{2}$ \\
\hline $\begin{array}{r}0 \\
I-2 \\
>2\end{array}$ & $\begin{array}{r}46 \\
\text { 10 } \\
5\end{array}$ & $\begin{array}{r}35 \\
8 \\
18\end{array}$ & $\begin{array}{l}8 I \\
I 8 \\
23\end{array}$ & $\begin{array}{l}\mathrm{I} \cdot 493 \\
0 \cdot 222 \\
7 \cdot 347\end{array}$ \\
\hline Mean & 0.67 & I. 57 & $\ldots$ & $9 \cdot 062$ \\
\hline
\end{tabular}

Difference 0.90 significant $; \chi^{2}=9 \cdot 062 ; \nu=2 ; P=0 \cdot 02-0 \cdot 01$

(b) Second sample, 1949, of 6t individuals for each sex

\begin{tabular}{|c|c|c|c|c|}
\hline $\begin{array}{c}\text { Number of } \\
\text { irregularities }\end{array}$ & $o$ & 0 & Total & $\chi^{2}$ \\
\hline 0 & 28 & 27 & 55 & 0.018 \\
$1-2$ & 9 & 11 & 20 & 0.200 \\
$3-4$ & 72 & 19 & 1.315 \\
$>4$ & 12 & 16 & 28 & 0.571 \\
\hline Mean & 2.09 & $2 \cdot 36$ & $\ldots$ & 2.104 \\
\hline
\end{tabular}

Difference 0.27 not surely significant $; \chi^{2}=2 \cdot 104 ; \nu=3 ; P=0.70-0.50$

One remarks that in two subsequent years the difference between sexes is decreased for both characters, more clearly for the corneal irregularities, although both characters showed formerly a significant difference between sexes.

\section{CRKWENIKA}

r. Hairs.-One hundred individuals for each sex.

\begin{tabular}{|c|c|c|c|c|c|c|c|c|c|c|c|c|c|c|c|}
\hline \multicolumn{2}{|c|}{ Number of hairs } & & & ro & $I I$ & 12 & 13 & 14 & 15 & ${ }^{16}$ & 17 & 18 & 19 & 20 & $2 I$ \\
\hline $\begin{array}{l}q . \\
d^{\circ} .\end{array}$ & $\dot{ }$ & & • & $\begin{array}{l}1 \\
\cdots\end{array}$ & $\ldots$ & $\begin{array}{c}4 \\
\cdots\end{array}$ & $\begin{array}{r}14 \\
4\end{array}$ & $\begin{array}{r}17 \\
8\end{array}$ & $\begin{array}{l}25 \\
22\end{array}$ & $\begin{array}{l}16 \\
18\end{array}$ & $\begin{array}{l}14 \\
17\end{array}$ & $\begin{array}{r}5 \\
\text { ro }\end{array}$ & $\begin{array}{r}3 \\
15\end{array}$ & $\dddot{5}$ & $\begin{array}{l}1 \\
1\end{array}$ \\
\hline
\end{tabular}

Mean $+I_{5} \cdot{ }_{5}$ Difference $1 \cdot 42 \pm 0 \cdot 258$ significant Mean ơ 16.57

Corneal size and irregularities not investigated. 


\section{Luino}

I. Hairs.-One hundred individuals for each sex.

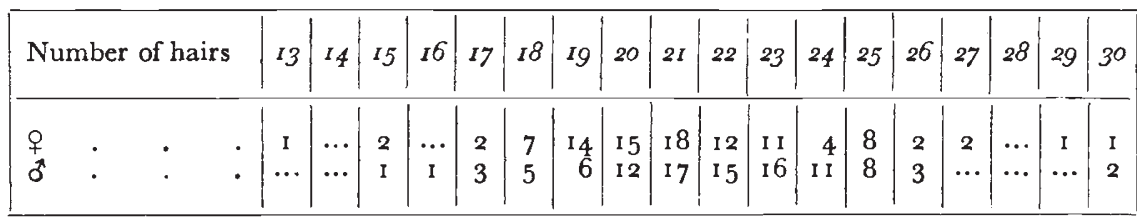

Mean $q 21 \cdot 25$ Difference $0 \cdot 5^{8} \pm 0 \cdot 377$ not significant

Mean ơ $21 \cdot 83$

2. Cornea.-Thirty individuals for each sex (see table 2) :-

TABLE 2

Surface in $\mu^{2}$ of the cornee of Crkwenika

\begin{tabular}{|c|c|c|c|c|c|c|c|c|c|}
\hline \multicolumn{5}{|c|}{ 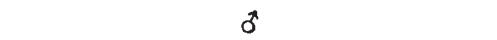 } & \multicolumn{5}{|c|}{ 우 } \\
\hline $\begin{array}{l}502 \\
518 \\
580 \\
588 \\
603 \\
603\end{array}$ & $\begin{array}{l}607 \\
611 \\
626 \\
630 \\
635 \\
635\end{array}$ & $\begin{array}{l}678 \\
678 \\
693 \\
699 \\
727 \\
733\end{array}$ & $\begin{array}{l}733 \\
742 \\
742 \\
743 \\
75^{2} \\
753\end{array}$ & $\begin{array}{l}795 \\
876 \\
887 \\
887 \\
943 \\
949\end{array}$ & $\begin{array}{l}542 \\
547 \\
551 \\
578 \\
582 \\
601\end{array}$ & $\begin{array}{l}601 \\
606 \\
629 \\
643 \\
648 \\
648\end{array}$ & $\begin{array}{l}652 \\
657 \\
657 \\
686 \\
696 \\
701\end{array}$ & $\begin{array}{l}701 \\
710 \\
715 \\
731 \\
731 \\
749\end{array}$ & $\begin{array}{l}762 \\
782 \\
793 \\
803 \\
808 \\
896\end{array}$ \\
\hline $\begin{array}{l}\text { Total } \\
\text { Means }\end{array}$ & & \multicolumn{3}{|c|}{$\begin{array}{c}30 \\
704^{\circ} \cdot 933\end{array}$} & \multicolumn{5}{|c|}{$68^{30} \cdot 200$} \\
\hline
\end{tabular}

Difference $24.733 ; t=\frac{24 \cdot 733}{26.675}=0.927 ; \nu=58 ; \quad \mathrm{P}<0.4$. Difference not significant.

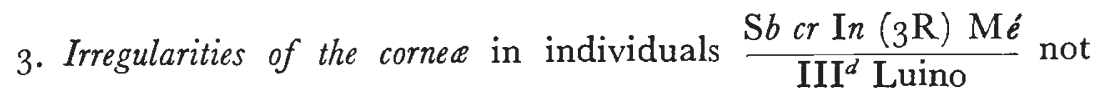
investigated.

One remarks that the difference between sexes is not significant in both the tested characters.

\section{GENERAL CONCLUSIONS ON THE WILD STOCKS}

I. The most general fact observed is the higher cellular size in the female. This is demonstrated by the smaller frequency of unicellular hairs in a given surface of the wing and the greater size of the cornex.

2. The difference between sexes is different in different stocks, being significant for all the considered characters. The difference is significant in Oregon, Oerlikon and Crkwenika, and not in Luino.

The possible explanation for the phenomena is that the $\mathrm{Y}$ - or the X-chromosomes could be responsible of a control on the characters under consideration. 
To decide what an alternative may be true, the following experiment has been designed : to bring the $\mathrm{Y}$ of one stock with a low sex difference into one stock where the difference is high, or vice versa. Since the stocks showing the most striking discrepancy in sex difference are Oregon $\mathrm{R}$ and Luino, it seemed opportune to bring together the $\mathrm{Y}$ of Luino with the other chromosomes of Oregon. The expectation is :-

(a) If $\mathrm{Y}$ plays a prominent role in controlling the considered characters, the combination of $\mathrm{Y}$ of Luino with the Oregon set will produce the insignificant difference between sexes, which seems typical for Luino.

(b) If that is not true, and different parts of the genome take part in the control, the sex difference of Luino will not be observed.

The following data have been obtained after two independent oregonisations with the method of the repeated crosses (see page 416), in order to ascertain if the procedure can give homogeneous results. The stock obtained is labelled "Luino oregonised."

Hairs.-From these data the analysis of the variance was used to prove if the 4 samples, two of males and two of females, obtained in both oregonisations belong to the same population.

Number of individuals.-First sample : 30 for each sex. Second sample : i 5 for each sex.

\begin{tabular}{|c|c|c|c|c|c|}
\hline \multicolumn{3}{|c|}{ First sample } & \multicolumn{3}{|c|}{ Second sample } \\
\hline Number of hairs & $\sigma^{*}$ & $q$ & Number of hairs & $\sigma$ & q \\
\hline 14 & 1 & $\ldots$ & 15 & $\ldots$ & 2 \\
\hline 15 & $\ldots$ & $\ldots$ & 16 & 4 & $\ldots$ \\
\hline 16 & $\begin{array}{l}4 \\
6\end{array}$ & 3 & 17 & 4 & 3 \\
\hline $\begin{array}{l}17 \\
18\end{array}$ & $\begin{array}{l}6 \\
8\end{array}$ & 4 & 18 & 4 & 4 \\
\hline 19 & 9 & 4 & 20 & 3 & $\begin{array}{l}5 \\
\ldots\end{array}$ \\
\hline 20 & 2 & 5 & $\ldots$ & $\ldots$ & $\ldots$ \\
\hline $2 I$ & $\cdots$ & 3 & $\cdots$ & $\cdots$ & $\cdots$ \\
\hline
\end{tabular}

As a test of homogeneity of the two stocks obtained through independent oregonisations the frequency of hairs of which is given in the following table, an analysis of variance was carried out. The results of the analysis given below showed no significant heterogeneity.

Analysis of variance

\begin{tabular}{|c|c|c|c|c|c|}
\hline $\begin{array}{l}\text { Variance between four } \\
\text { series }\end{array}$ & df 3 & SS $11 \cdot 94$ & var. 3.98 & $\mathrm{~F} 2 \cdot 101$ & $\mathrm{P}>5$ per cent. \\
\hline Variance between sexes & 1 & 4.90 & $4 \cdot 90$ & $2 \cdot 587$ & $>5 \quad "$ \\
\hline $\begin{array}{l}\text { Residual (sex difference }+ \\
\text { interaction) }\end{array}$ & 2 & $7 \cdot 04$ & $3 \cdot 52$ & $x \cdot 859$ & $>_{5}$ \\
\hline Variance within samples & 86 & ... & $1 \cdot 894$ & $\cdots$ & $\cdots$ \\
\hline
\end{tabular}


Cornee.-First sample : 29 individuals for each sex (see Table 3). Second sample : i 5 females, i 3 males.

TABLE 3

Surfaces in $\mu^{2}$ of the cornere of "Luino oregonised"

\begin{tabular}{|c|c|c|c|c|c|c|c|c|c|}
\hline \multicolumn{5}{|c|}{ t } & \multicolumn{5}{|c|}{ q } \\
\hline $\begin{array}{l}657 \\
666 \\
668 \\
694 \\
695 \\
710\end{array}$ & $\begin{array}{l}720 \\
724 \\
732 \\
755 \\
766 \\
778\end{array}$ & $\begin{array}{l}786 \\
800 \\
800 \\
817 \\
825 \\
839\end{array}$ & $\begin{array}{l}840 \\
855 \\
886 \\
894 \\
905 \\
913\end{array}$ & $\begin{array}{c}922 \\
926 \\
928 \\
948 \\
95^{1} \\
\ldots\end{array}$ & $\begin{array}{l}692 \\
705 \\
726 \\
729 \\
75^{\circ} \\
75^{2}\end{array}$ & $\begin{array}{l}75^{2} \\
761 \\
762 \\
772 \\
789 \\
793\end{array}$ & $\begin{array}{l}795 \\
804 \\
836 \\
836 \\
839 \\
841\end{array}$ & $\begin{array}{l}871 \\
888 \\
893 \\
895 \\
913 \\
930\end{array}$ & $\begin{array}{r}931 \\
949 \\
965 \\
994 \\
\text { I } 033 \\
\ldots\end{array}$ \\
\hline $\begin{array}{l}\text { Total } \\
\text { Means }\end{array}$ & \multicolumn{3}{|c|}{$\stackrel{29}{806 \cdot 98}$} & & \multicolumn{5}{|c|}{$\begin{array}{c}29 \\
834^{\circ} 34\end{array}$} \\
\hline
\end{tabular}

Difference $27 \cdot 45 ; \quad t=\frac{27 \cdot 45}{23 \cdot 4^{2}}=1 \cdot 17 ; \quad \nu=56 ; \mathrm{P}=0 \cdot 3$. Difference not significant.

The second sample gave the following means : females, $\mu^{2} 73^{8} \cdot 64$; males, $\mu^{2} 744 \cdot 77$; difference, $\mu^{2} 5 \cdot 07$. Since the difference in the first sample is not significant, and in the second one it is even less, no further statistical calculation has been carried on.

Irregularities of the cornee in the individuals $* \frac{\mathrm{S} b \mathrm{cr} \text { In }\left({ }_{3} \mathrm{R}\right) \mathrm{M} \dot{e}}{\text { III Luino Oreg }}$.

Number of individuals oo for each sex.

\begin{tabular}{|c|c|c|c|c|}
\hline $\begin{array}{l}\text { Number of } \\
\text { irregularities }\end{array}$ & 우 & d & Total & $\chi^{2}$ \\
\hline $\begin{array}{r}o \\
>0\end{array}$ & $\begin{array}{l}86 \\
14\end{array}$ & $\begin{array}{l}87 \\
\mathrm{I} 3\end{array}$ & $\begin{array}{r}173 \\
27\end{array}$ & $\begin{array}{l}0.005 \\
0.037\end{array}$ \\
\hline Mean & 0.18 & 0.18 & $\ldots$ & $0.04^{2}$ \\
\hline
\end{tabular}

Difference $0 ; \chi^{2}=0.042 ; \nu=1 ; \mathrm{P}>0.80$. Distribution not significantly different.

One sees that in all three characters no significant difference between sexes appears. This is in agreement with the hypothesis of prominent influence of the $\mathrm{Y}$-chromosome.

One possible objection is that the low difference between sexes could be a general effect arising from a new arrangement of different gene systems, produced during the genome substitution.

To remove this objection a second substitution was made between two stocks with high difference between sexes: in this case the expectation according to the Y-chromosome hypothesis is that a high difference should be found.

* These data have been collected by my assistant Dr A. Di Pasquale. 
The synthesis of $\mathrm{Y}$ and other chromosomes was made using the balanced stocks, as described on page $4^{\mathrm{I}} 6$.

The stocks chosen were Oregon as $\mathrm{Y}$ donor and Crkwenika for the remainder set.

This investigation was limited to the hairs.

Number of individuals $\mathrm{I} 5 \mathrm{O}$ for each sex.

\begin{tabular}{|c|c|c|c|c|c|c|c|c|c|c|c|c|}
\hline & hairs & $I 6$ & $I 7$ & 18 & 19 & 20 & $2 I$ & 22 & 23 & 24 & 25 & 26 \\
\hline $\begin{array}{c}q \\
0 \\
\sigma^{\prime}\end{array}$ & : & $\begin{array}{c}4 \\
. .\end{array}$ & $\begin{array}{l}2 \\
2\end{array}$ & $\begin{array}{l}7 \\
3\end{array}$ & $\begin{array}{l}11 \\
13\end{array}$ & $\begin{array}{c}\text { Io } \\
9\end{array}$ & $\begin{array}{l}6 \\
9\end{array}$ & $\begin{array}{l}6 \\
6\end{array}$ & $\begin{array}{l}3 \\
3\end{array}$ & ... & $\ldots$ & I \\
\hline
\end{tabular}

Mean ơ $20 \cdot 56$ Difference $0 \cdot 84 \pm 0 \cdot 4^{16}$

Mean $q$ 1 $9 \cdot 72$

The difference is probably significant

One sees that in this case the difference between sexes remained at the same order of magnitude before and after the substitution of chromosomes (before $1 \cdot 42 \pm 0 \cdot 258$, after $0 \cdot 84 \pm 0 \cdot 416$ ).

C.-A further comparison between the oregonised stocks and the original ones Oregon and Luino is obtained with the following analysis of the variance.

The table summarises the data concerning the comparison for hair frequency of Oregon, Luino and Luino oregonised.

The data are tabulated on pages $4 \mathrm{I} 8$ (Oregon second sample), $42 \mathrm{I}$ and 422 .

\begin{tabular}{|c|c|c|c|c|c|c|}
\hline & \multicolumn{2}{|c|}{ Oregon } & \multicolumn{2}{|c|}{ Luino oregonised } & \multicolumn{2}{|c|}{ Luino } \\
\hline & 우 & $\sigma^{*}$ & q & $\sigma^{*}$ & 우 & $\sigma^{*}$ \\
\hline $\begin{array}{l}\text { Total number of flies } \\
\text { Means }\end{array}$ & $\begin{array}{l}100 \\
14 \cdot 63\end{array}$ & $\begin{array}{l}100 \\
17 \cdot 33\end{array}$ & $\begin{array}{l}45 \\
16 \cdot 70\end{array}$ & $\begin{array}{c}45 \\
17 \cdot 25\end{array}$ & $\begin{array}{c}100 \\
21 \cdot 25\end{array}$ & $\begin{array}{c}100 \\
21 \cdot 83\end{array}$ \\
\hline Sex difference . & \multicolumn{2}{|c|}{$2 \cdot 70$} & \multicolumn{2}{|c|}{0.55} & \multicolumn{2}{|c|}{0.48} \\
\hline
\end{tabular}

These data were subjected to an analysis of variance, with partition of the five degrees of freedom of the variance between the six samples into orthogonal components, according to the following scheme :-

\begin{tabular}{|c|c|c|c|c|c|c|}
\hline \multirow{2}{*}{$\begin{array}{l}\text { Degree of freedom } \\
\quad \text { (see text) }\end{array}$} & \multicolumn{2}{|c|}{ Oregon } & \multicolumn{2}{|c|}{ Luino oregonised } & \multicolumn{2}{|c|}{ Luino } \\
\hline & 우 & $\sigma^{*}$ & 오 & $\delta$ & 우 & $\sigma^{*}$ \\
\hline $\begin{array}{l}\mathrm{A} \\
\mathrm{B} \\
\mathrm{C} \\
\mathrm{D} \\
\mathrm{E}\end{array}$ & $\begin{array}{l}+1 \\
-1 \\
\ldots \\
+2 \\
+1\end{array}$ & $\begin{array}{c}+1 \\
-1 \\
\ldots \\
-2 \\
-1\end{array}$ & $\begin{array}{l}-1 \\
-1 \\
+1 \\
-1 \\
+1\end{array}$ & $\begin{array}{l}-I \\
-I \\
-I \\
+I \\
-I\end{array}$ & $\begin{array}{l}\ldots \\
+2 \\
-1 \\
-1 \\
+1\end{array}$ & $\begin{array}{l}\ldots \\
+2 \\
+1 \\
+1 \\
+1\end{array}$ \\
\hline
\end{tabular}


In the table simple coefficients have been indicated. Since there was a difference of the number of individuals per group, the analysis had to be weighted.

In the above partition, $\mathrm{E}$ is put in merely to fill the analysis, and tests the significance of the total sex difference, irrespective of stocks. A and B refer to differences between stocks, irrespective of sex difference, A comparing Oregon with Luino oregonised, and B comparing the sum of Oregon and Luino oregonised with Luino. $\mathrm{C}$ and $\mathrm{D}$ test the significance of sex differences, $\mathrm{C}$ comparing the sex difference of Luino with that of Luino oregonised, and $\mathrm{D}$ the pooled sex difference of these two stocks to the sex difference of Oregon.

The results of the analysis are then :-

\begin{tabular}{|c|c|c|c|}
\hline Degree of freedom & $\begin{array}{l}\text { Variance }= \\
\text { sum of square }\end{array}$ & $t$ & P (per cent.) \\
\hline $\begin{array}{l}\text { A. Difference between Oregon and oregonised } \\
\text { Luino stocks }\end{array}$ & $60 \cdot 4^{2}$ & $3 \cdot 63$ & $<0.01$ \\
\hline $\begin{array}{l}\text { B. Difference between Luino and pooled } \\
\text { Oregon and oregonised Luino stocks }\end{array}$ & $3^{26} 7 \cdot 23$ & $8 \cdot 47$ & o \\
\hline $\begin{array}{l}\text { C. Difference between sex-differences of } \\
\text { Luino and oregonised Luino }\end{array}$ & $0 \cdot 01$ & 0.002 & $>95$ \\
\hline $\begin{array}{l}\text { D. Same between Oregon and pooled Luinot } \\
\text { oregonised Luino }\end{array}$ & $133 \cdot 95$ & $5 \cdot 4 I$ & $<$ oor \\
\hline E. Sex difference, total & $254 \cdot 30$ & $7 \cdot 46$ & o \\
\hline $\begin{array}{l}\text { Total sum of squares between samples } \\
\text { Variance within samples sum of squares . }\end{array}$ & $\begin{array}{l}3715 \cdot 91 \\
2218 \cdot 26\end{array}$ & $\begin{array}{l}\text { df. } \\
\text { df. } 485\end{array}$ & $\begin{array}{l}\cdots \\
\cdots\end{array}$ \\
\hline Mean square & 4.574 & $\cdots$ & $\cdots$ \\
\hline
\end{tabular}

All these variances have one degree of freedom, and hence the $t$ test can be used for testing significance. It will be seen that the three stocks differ among themselves, when the sex difference is disregarded and both sexes pooled. However, it is clear that Luino oregonised is nearer to Oregon than to Luino, which fact shows the effect of the

\begin{tabular}{|c|c|c|c|c|c|c|c|}
\hline & \multicolumn{2}{|c|}{ Oregon } & \multicolumn{2}{|c|}{ Luino oregonised } & \multicolumn{2}{|c|}{ Luino } \\
\hline & & 우 & d & 우 & o & 우 & $\delta$ \\
\hline $\begin{array}{l}\text { Mean } \\
\text { Number : }\end{array}$ & $\cdot \quad \cdot$ & $\begin{array}{c}840 \cdot 90 \\
30\end{array}$ & $\begin{array}{c}732 \cdot 00 \\
30\end{array}$ & $\begin{array}{c}801 \cdot 71 \\
44\end{array}$ & $\begin{array}{c}787 \cdot 63 \\
42\end{array}$ & $\begin{array}{c}680 \cdot 20 \\
30\end{array}$ & $\begin{array}{c}704 \cdot 93 \\
3^{\circ}\end{array}$ \\
\hline Sex difference & . & \multicolumn{2}{|c|}{+108.90} & \multicolumn{2}{|c|}{+14.07} & \multicolumn{2}{|c|}{$-24 \cdot 73$} \\
\hline
\end{tabular}

genome on the character. On the other hand, when sex differences are considered, no difference can be observed between Luino and oregonised Luino (comparison C), the only thing in common between the two stocks being the Y-chromosome; while the sex difference 
observed in these two strains taken together is highly significantly different from the sex difference observed in Oregon (comparison D), nd here the only genotypic difference among the first two stocks nd the latter is the Y-chromosome.

The same procedure has been applied to the analysis of corneæ surface, with the previous and following results (data on corneæ, see p. 425$):-$

\begin{tabular}{|c|c|c|c|}
\hline Degree of freedom & $\begin{array}{l}\text { Variance }= \\
\text { sum of square }\end{array}$ & $t$ & $P$ (per cent.) \\
\hline A. Difference between Oregon and oregonised & $23 \cdot 5^{\circ}$ & $0.5 I$ & 60 \\
\hline $\begin{array}{l}\text { Luino stocks } \\
\text { B. Difference between Luino and pooled } \\
\text { Oregon and oregonised Luino stocks }\end{array}$ & $4141 \cdot 46$ & $6 \cdot 77$ & o \\
\hline $\begin{array}{l}\text { C. Difference between sex differences of Luino } \\
\text { and oregonised Luino }\end{array}$ & $9 \cdot 74$ & 0.33 & $>50$ \\
\hline $\begin{array}{l}\text { D. Difference between sex difference of Oregon } \\
\text { and pooled Luino and oregonised Luino }\end{array}$ & $1426 \cdot 74$ & $3 \cdot 96$ & $<0.1$ \\
\hline E. Sex difference, total & $477 \cdot 70$ & $2 \cdot 30$ & $<5$ \\
\hline $\begin{array}{l}\text { Total sum of squares, variance between } \\
\text { samples }\end{array}$ & $6079 \cdot 14$ & df. 5 & $\ldots$ \\
\hline Variance within samples, mean square & $90 \cdot 54$ & df. 200 & $\ldots$ \\
\hline
\end{tabular}

(For this analysis I am indebted to the courtesy of Dr L. Cavalli-Sforza.)

The conclusions which can be drawn from the analysis are that, since the difference between Oregon and oregonised Luino is not significant for the cornex but significant for the hairs, the first character shows a participation of different parts of the genome beyond the $Y$ chromosome. What is important is that in both cases the sex difference in Oregon and in oregonised Luino does not show any significant difference.

D.-As a further step to control the conclusions reached from the previous observations, reciprocal crosses were made to test if the presence of a given $\mathrm{Y}$ could produce high or low sex difference.

TABLE 4

Heterozygous 우 from Luino 우 $\times$ Oregon $\sigma^{*}$

\begin{tabular}{|c|c|c|c|c|c|}
\hline & I & II & III & IV & $\mathrm{V}$ \\
\hline \multirow[t]{2}{*}{$\begin{array}{l}1 \\
2 \\
3 \\
4 \\
5\end{array}$} & $\begin{array}{l}850 \\
633 \\
774 \\
660 \\
774\end{array}$ & $\begin{array}{l}735 \\
962 \\
881 \\
711 \\
945\end{array}$ & $\begin{array}{l}774 \\
850 \\
735 \\
840 \\
794\end{array}$ & $\begin{array}{l}789 \\
789 \\
735 \\
829 \\
721\end{array}$ & $\begin{array}{l}934 \\
740 \\
716 \\
885 \\
779\end{array}$ \\
\hline & $73^{8} \cdot 2$ & $846 \cdot 8$ & 798.6 & $772 \cdot 6$ & $8 \times 0.8$ \\
\hline
\end{tabular}

General mean $793^{\circ} 4$

The stocks wild Luino and Oregon were chosen, treated with the following technique. 
Single pairs of female Luino $\times$ male Oregon and vice versa were put in culture bottles, and from each culture five individuals were taken to measure the cornex.

To abbreviate the work, the number of individuals kept low; but to ascertain if from the five cultures a homogenous material has been raised, the data were first submitted to an analysis of the variance, using the $\mathrm{F}$ test, as it is shown in the previous and following tables :-

\begin{tabular}{|c|c|c|c|}
\hline & Sum of squares & Degrees of freedom & Variance \\
\hline $\begin{array}{l}\text { Variance between groups } \\
\text { Variance within groups }\end{array}$ & $\begin{array}{l}39,786 \cdot 80 \\
33,305 \cdot 20\end{array}$ & $\begin{array}{r}20 \\
4\end{array}$ & $\begin{array}{l}6,989,34 \\
8,326 \cdot 30\end{array}$ \\
\hline Total variance & $173,092 \cdot 00$ & 24 & $7,212 \cdot 167$ \\
\hline
\end{tabular}

$$
\mathbf{F}<\mathbf{1} \text {. }
$$

The difference among the samples is not significant, thus the samples can be pooled.

Heterozygous ơ from Luino + $\times$ Oregon $\sigma^{*}$

\begin{tabular}{|l|l|l|l|l|l|}
\hline & I & II & III & IV & V \\
\hline & & & & \\
\hline 1 & 902 & 669 & 824 & 824 & 669 \\
2 & 665 & 581 & 615 & 665 & 633 \\
3 & 774 & 814 & 665 & 794 & 611 \\
4 & 530 & 886 & 688 & 809 & 611 \\
5 & 692 & 834 & 678 & 678 & 568 \\
\cline { 2 - 6 } & $\mathbf{7 1 2 \cdot 6}$ & $\mathbf{7 5 6 \cdot 8}$ & $\mathbf{6 9 4 \cdot 0}$ & $\mathbf{7 5 4 \cdot 0}$ & $\mathbf{6 1 8 \cdot 4}$ \\
\hline
\end{tabular}

\begin{tabular}{|l|c|c|c|}
\hline & Sum of squares & Degrees of freedom & Variance \\
\cline { 2 - 4 } $\begin{array}{l}\text { Variance between groups } \\
\text { Variance within groups }\end{array}$ & $\begin{array}{r}193,133 \cdot 08 \\
63,696 \cdot 20\end{array}$ & 20 & $\begin{array}{r}9,656 \cdot 65 \\
\mathrm{r} 5,924 \cdot 05\end{array}$ \\
\cline { 2 - 4 } Total variance & $256,829 \cdot 28$ & 24 & $10,791 \cdot 22$ \\
\hline
\end{tabular}

$$
\mathrm{F}<\mathrm{I} \text {. }
$$

The difference among the samples is not significant, thus they can be pooled.

The comparison of the mean for males and females, using the $t$ test gave the following result (see table 5).

The difference between sexes of heterozygous, where the $\mathrm{Y}$ is derived from the Oregon stock, is thus significant.

For the reciprocal cross (female Oregon $\times$ male Luino), the same treatment is here summarised (see table 6). 
TABLE 5

Surfaces in $\mu^{2}$ of the cornee of the heterozygous Oregon $\delta \times$ Luino $q$

\begin{tabular}{|c|c|c|c|c|c|c|c|c|c|}
\hline \multicolumn{5}{|c|}{$\sigma^{x}$} & \multicolumn{5}{|c|}{ ㅇ } \\
\hline $\begin{array}{l}530 \\
568 \\
581 \\
611 \\
611\end{array}$ & $\begin{array}{l}615 \\
633 \\
665 \\
665 \\
665\end{array}$ & $\begin{array}{l}669 \\
669 \\
678 \\
678 \\
688\end{array}$ & $\begin{array}{l}692 \\
774 \\
794 \\
809 \\
814\end{array}$ & $\begin{array}{l}824 \\
824 \\
834 \\
886 \\
902\end{array}$ & $\begin{array}{l}633 \\
660 \\
711 \\
716 \\
721\end{array}$ & $\begin{array}{l}735 \\
735 \\
740 \\
774 \\
774\end{array}$ & $\begin{array}{l}774 \\
779 \\
789 \\
789 \\
794\end{array}$ & $\begin{array}{l}829 \\
840 \\
850 \\
850 \\
881\end{array}$ & $\begin{array}{l}885 \\
934 \\
935 \\
945 \\
962\end{array}$ \\
\hline \multicolumn{2}{|c|}{$\begin{array}{l}\text { Total } \\
\text { Means }\end{array}$} & \multicolumn{3}{|c|}{$\begin{array}{c}25 \\
707 \cdot 400\end{array}$} & \multicolumn{5}{|c|}{$\begin{array}{c}25 \\
793 \cdot 400\end{array}$} \\
\hline
\end{tabular}

Difference $86 \cdot 24 ; t=\frac{86 \cdot 240}{26 \cdot 768}=3 \cdot 222 ; \nu=48 ; \mathrm{P}=0 \cdot 00 \mathrm{r}$. The difference is significant.

TABLE 6

Heterozygous of from Oregon + $\times$ Luino $\delta$

\begin{tabular}{|c|c|c|c|c|c|}
\hline & I & II & III & IV & $\mathrm{V}$ \\
\hline \multirow[t]{2}{*}{$\begin{array}{l}\mathrm{I} \\
2 \\
3 \\
4 \\
5\end{array}$} & $\begin{array}{l}651 \\
876 \\
702 \\
913 \\
745 \\
\end{array}$ & $\begin{array}{l}651 \\
669 \\
724 \\
789 \\
730\end{array}$ & $\begin{array}{r}642 \\
745 \\
870 \\
855 \\
1009\end{array}$ & $\begin{array}{l}945 \\
907 \\
702 \\
829 \\
934\end{array}$ & $\begin{array}{l}609 \\
824 \\
814 \\
745 \\
865\end{array}$ \\
\hline & $777 \cdot 4$ & $712 \cdot 0$ & $824 \cdot 2$ & $86_{3} \cdot 4$ & $783 \cdot 4$ \\
\hline
\end{tabular}

General mean $792 \cdot 2$

\begin{tabular}{|l|c|c|c|}
\hline & Sum of squares & Degrees of freedom & Variance \\
\cline { 2 - 4 } $\begin{array}{l}\text { Variance between groups } \\
\text { Variance within groups }\end{array}$ & $\begin{array}{r}204,035 \cdot 60 \\
63,630 \cdot 40\end{array}$ & 20 & $\begin{array}{c}10,201 \cdot 78 \\
15,907 \cdot 60\end{array}$ \\
\hline Total variance & $267,666 \cdot 00$ & 24 & $11,152 \cdot 75$ \\
\hline
\end{tabular}

$\mathrm{F}<\mathrm{i}$

The differences among the samples are not significant, and the samples can be pooled.

Heterozygous ơ from Oregon + $\times$ Luino ơ

\begin{tabular}{|c|c|c|c|c|c|}
\hline & I & II & III & IV & V \\
\hline \multirow[t]{2}{*}{$\begin{array}{l}\text { I } \\
2 \\
3 \\
4 \\
5\end{array}$} & $\begin{array}{r}871 \\
1012 \\
876 \\
745 \\
740\end{array}$ & $\begin{array}{l}740 \\
716 \\
678 \\
716 \\
721\end{array}$ & $\begin{array}{l}740 \\
870 \\
678 \\
740 \\
814\end{array}$ & $\begin{array}{l}735 \\
740 \\
918 \\
660 \\
865\end{array}$ & $\begin{array}{l}794 \\
870 \\
907 \\
907 \\
789\end{array}$ \\
\hline & $848 \cdot 8$ & $714 \cdot 2$ & $768 \cdot 4$ & $783 \cdot 6$ & 853.4 \\
\hline
\end{tabular}

General mean $793 \cdot 68$ 


\begin{tabular}{|c|c|c|c|}
\hline & Sum of squares & Degrees of freedom & Variance \\
\hline $\begin{array}{l}\text { Variance between groups } \\
\text { Variance within groups }\end{array}$ & $\begin{array}{l}\mathrm{I} 32,62 \mathrm{I} \cdot \mathrm{I} 48 \\
68,3 \mathrm{I} \cdot 3 \mathrm{O}\end{array}$ & $\begin{array}{r}20 \\
4\end{array}$ & $\begin{array}{r}6,631 \cdot 05 \\
17,078 \cdot 07\end{array}$ \\
\hline Total variance & $200,933 \cdot 44^{8}$ & 24 & $8,372 \cdot 227$ \\
\hline
\end{tabular}

$\mathrm{F}<\mathrm{I}$

The differences among the samples are not significant, and the samples can be pooled.

The measures of the females are then compared with those of the males (see table 7) :-

TABLE 7

Surfaces in $\mu^{2}$ of the cornee of the heterozygous Luino $\sigma \times$ Oregon + ?

\begin{tabular}{|c|c|c|c|c|c|c|c|c|c|}
\hline \multicolumn{5}{|c|}{ o } & \multicolumn{5}{|c|}{ 우 } \\
\hline $\begin{array}{l}642 \\
65 \mathrm{I} \\
65 \mathrm{I} \\
669 \\
669\end{array}$ & $\begin{array}{l}702 \\
702 \\
724 \\
730 \\
745\end{array}$ & $\begin{array}{l}745 \\
745 \\
789 \\
814 \\
824\end{array}$ & $\begin{array}{l}829 \\
855 \\
865 \\
870 \\
876\end{array}$ & $\begin{array}{r}907 \\
9^{113} \\
934 \\
945 \\
1009\end{array}$ & $\begin{array}{l}660 \\
678 \\
678 \\
716 \\
716\end{array}$ & $\begin{array}{l}72 \mathrm{I} \\
735 \\
740 \\
740 \\
740\end{array}$ & $\begin{array}{l}740 \\
745 \\
789 \\
794 \\
814\end{array}$ & $\begin{array}{l}865 \\
870 \\
870 \\
871 \\
876\end{array}$ & $\begin{array}{l}9^{07} \\
9^{07} \\
9^{18} \\
9^{18} \\
\ldots\end{array}$ \\
\hline $\begin{array}{l}\text { Total } \\
\text { Means } \\
\sigma^{2}\end{array}$ & \multicolumn{4}{|c|}{$\begin{array}{c}25 \\
79^{2 \cdot 20} \\
8,37^{2} \cdot 227\end{array}$} & \multicolumn{5}{|c|}{$\begin{array}{c}24 \\
793 \cdot 68 \\
\text { I I, I } 52 \cdot 75\end{array}$} \\
\hline
\end{tabular}

Difference $\mathrm{I} \cdot 4^{8}$

The difference is obviously not significant, thus no further statistical analysis has been made.

The general conclusion which can be reached is that the presence of the $\mathrm{Y}$ of Oregon and that of the $\mathrm{Y}$ of Luino produce different effect, consistent with the other observations.

\section{DISCUSSION}

The present investigations give the following information on whether diversities in sex difference are due to the Y-chromosomes or to other parts of the genome :-

(a) The sex difference does not change also after substitution of the chromosomes, when the Y-chromosome remains the same.

(b) In reciprocal crosses between a stock with high and a stock with low sex difference, when the Y-chromosome is provided by a stock with high sex difference, this remains high, and vice versa.

With this evidence, it is possible to discuss the hypothesis put forward in the introduction. 
The lack of a significant variation in the sex difference, after a substitution of all chromosomes except the Y, proves that the latter exerts a prominent role in acting on the analysed characters. The maternal effect, i.e. the influence of the egg plasma, can be excluded if one considers the results of the reciprocal crosses. In fact, with a maternal effect, the derivation of the egg from Oregon should give a great difference between sexes, and that of Luino a not significant difference; on the contrary, the individuals coming from eggs from the Oregon stock and carrying the $\mathrm{Y}$ from Luino do not show any significant sex difference. It is worth mentioning that no further comparative analysis can be made to exclude any egg influence, because the genotypes : egg Oregon-Y Oregon, egg Oregon-Y Luino, egg Luino-Y Luino, egg Luino-Y Oregon have been obtained in different periods of the investigation, and thus are not suitable for a comparison. We must be content to compare the reciprocal crosses : egg Oregon-Y Luino, egg Luino-Y Oregon, which have been produced in identical conditions and contemporarily and show closely similar figures. It therefore follows that the action of the $\mathrm{Y}$ is demonstrated, even when a participation of the egg plasma cannot be denied.

This action of the $\mathrm{Y}$ is expressed in not merely one, but three characters, in the same manner. That is, where the difference between sexes is not significant or significant for one character, the same is true for the others.

Obviously this observation leads to consider the genetical composition of the $\mathrm{Y}$-chromosome.

From a general point of view, the following hypotheses can be put forward :-

(a) Presence of ore gene for each character, all causally acting in the same manner.

(b) Presence of only one gene with an apparent pleiotropic activity.

(c) Presence of several genes provided of the same type of pleiotropy, building a system of polygenes.

The simultaneous presence of three genes acting in the same manner in the same $\mathrm{Y}$ (first hypothesis) seems the most unlikely. The second and the third hypotheses are more acceptable. According to them, the gene should be active in determining an average cell size, irrespective of the kind of tissue. In this case the pleiotropy only should be apparent.

To decide between the second and the third hypothesis (i.e. one gene or many genes) further investigations are needed. But also with the data available now, some elements can be found in favour of the hypothesis of polygenes. Above all, the results by Mather (1944) are clearly in favour of the existence of polygenes investigating one character (the sternopleural chetæ) closely similar to those considered in the present paper. Secondly, the behaviour of the stock Oerlikon, 
showing a decrease in sex difference during the one year's space recalls a finding already described by Mather. Thirdly, the variety of Y's found is consistent with the hyperthesis of many loci, responsible for the same action.

The possible presence of a system of polygenes in the chromosome acting on the cell size shows a relationship with the Caspersson's theory on the activity of the heterochromatin. If the heterochromatin is the centre where both nucleic acids are synthesised, the cell size must be also controlled by the genetical properties of the heterochromatin. In this view the most different organs may show a common trait dependent on the $\mathrm{Y}$-chromosome genotype, acting at the cellular level. On the other hand those genes, which act on polycellular characters, should be restricted in their control to distinct parts of the body.

This hypothetical view is not disproved by the data obtained from other material.

The influence of heterochromatin on the chaetæ number in Drosophila (Mather, I944) and on pollen-grain life in Sorghum (Darlington and Thomas, I94I) are comparable with the present results. The comparison with the variegation of Drosophila is less clear, but although not fully understood, it is none the less a disturbance in a character production, limited often to groups of a few cells.

As the present state of the investigation, generalisation seems premature. But, in Drosophila melanogaster it is possible to recognise in the heterochromatin of the Y-chromosome an homogeneity in the type of action, which fails to be found in the euchromatic portions of the set.

If further data should be found to give more support to this view expressed now as a mere working hypothesis, heterochromatin might be distinguished from euchromatin as being made up by genes acting in a similar manner on the cell size and other characters of the cell.

To the demonstration of the influence of the Y-chromosome is added the proof of the action of other chromosomes on the investigated characters. The analysis of the variance comparing males and females of Luino and Luino oregonised indicated that the samples are not homogeneous for the wing hairs. This means that, since many parts of the genome are different in the compared groups, these parts (which do not include the $\mathrm{Y}$ ) are also responsible. It can be concluded that the difference between the mean of each sex indicates the action of the $\mathrm{Y}$, but that the values of the means might be dependent also on other chromosomes.

It must be finally noted that a first approach to the clarification of the genetical determination of the cell size was made as early as I929 by Dobzhansky, using one of the characters studied in the present investigation, i.e. the wing hairs frequency. Although he did not reach any conclusion concerning heterochromatin, his general view is consistent with the theory of a genetical determination of the cell size, independently of chromosome number variations. 


\section{SUMMARY}

I. Three characters have been analysed in D. melanogaster: frequency of the unicellular wing hairs, size of the corneæ of the compound eyes, number of the irregularities among the cornex. All these characters appear dependent on the Y-chromosome as shown by the difference of frequency between sexes. This action on all characters is similar because, where the difference between sexes is significant (or not significant) for one, the same is true for the others.

2. Since all the characters studied are produced by differences of cell size, it seems that the action of the Y-chromosome is primarily exerted on the cell size.

3. An influence on the hair frequency seems proved also for the other parts of the genome, whose actions were, however, less precisely analysed.

4. The findings lead one to consider the heterochromatin of the $\mathrm{Y}$-chromosome mainly as the site of a system of genes (polygenes) acting on small characters detectable only with quantitative analysis.

\section{REFERENCES}

BARIgozzI, C. 1945-46. Differenze fenotipiche in popolazioni naturali di $D$. melanogaster ecc. Rend. Ist. Lomb. Sc. Lett., 79, 325-344.

BARIGOzZI, C. 1948. Role of the Y-chromosome in the determination of cell-size in D. melanogaster. Nature, 162,30 .

BARIGozZI, C. 1950. A general survey on heterochromatin. Portugalie Acta Biologica, Ser. A-Goldschmidt, $I, 594-620$.

CASpersson, T. 1950. Cell growth and cell function. Naturwissenschaften, 29, 33. New York : Norton \& Co.

CASPERSSON, T., AND SCHULTZ, J. I 938 . Nucleic acid metabolism of the chromosomes in relation to gene reproduction. Nature, 142,294 .

DARLINGTON, C. D. I939. The genetical and mechanical properties of the sex chromosomes. III. Cimex and the Heteroptera. 7. Gen., 39, ror-I37.

DARLINGTON, C. D., AND THOMAS, P. T. I94I. Morbid mitosis and the activity of the inert chromosomes. P.R.S., B, 130, 127-150.

DEMEREC, M. 1940. Genetic behaviour of euchromatic segments inserted into heterochromatin. Genetics, 25, 6 r8.

Demerec, M. I94I. The nature of changes in the white-Notch region, etc. P. Int. Gen. C. (7), 99-103.

Di PASQUALE, A. I95I. La manifestazione nell'occhio connessa con In (3R) Mé di $D$. melanogaster (in the press).

DoBzhaNsky, T. I929. The influence of the quantity and quality of chromosome material on the size of the cells in D. melanogaster. Arch. f. Entw., $115,363-379$.

KNAPP, E. 1935. Zur Frage der genetischen Aktivität des Heterochromatins usw. Ber. deut. bot. Gesell., 53, 751-760.

MAther, K. I944. The genetical activity of heterochromatin. P.R.S., B, 132. 308-332.

oestergren, G. 1947. Heterochromatin B chromosomes in Anthoxantum. Hereditas, $33,26 \mathrm{r}-296$.

schultz, J. 1941. The function of heterochromatin. P. Int. Gen. C. (7), 257-262.

schultz, J. 1947. The nature of heterochromatin. Symp. Quant. Biol., 12, I 79-191. 